\title{
Getting to the core of cadherin complex function in
}

\section{Caenorhabditis elegans [version 1; peer review: 3 approved]}

\section{Jeff Hardin}

Department of Zoology, University of Wisconsin-Madison, Madison, WI, USA
V1 First published: 18 Dec 2015, 4(F1000 Faculty Rev):1473

https://doi.org/10.12688/f1000research.6866.1

Latest published: 18 Dec 2015, 4(F1000 Faculty Rev):1473

https://doi.org/10.12688/f1000research.6866.1

\begin{abstract}
The classic cadherin-catenin complex (CCC) mediates cell-cell adhesion in metazoans. Although substantial insights have been gained by studying the CCC in vertebrate tissue culture, analyzing requirements for and regulation of the CCC in vertebrates remains challenging. Caenorhabditis elegans is a powerful system for connecting the molecular details of CCC function with functional requirements in a living organism. Recent data, using an "angstroms to embryos" approach, have elucidated functions for key residues, conserved across all metazoans, that mediate cadherin/ $\beta$-catenin binding. Other recent work reveals a novel, potentially ancestral, role for the $C$. elegans p120ctn homologue in regulating polarization of blastomeres in the early embryo via Cdc42 and the partitioning-defective (PAR)/atypical protein kinase C (aPKC) complex. Finally, recent work suggests that the CCC is trafficked to the cell surface via the clathrin adaptor protein complex 1 (AP-1) in surprising ways. These studies continue to underscore the value of $C$. elegans as a model system for identifying conserved molecular mechanisms involving the CCC.
\end{abstract}

\section{Keywords}

Caenorhabditis elegans, C. elegans, classic cadherin-catenin complex, cadherin, $\beta$-catenin

\section{Open Peer Review \\ Approval Status \\ 1 \\ 2 \\ 3 \\ version 1 \\ 18 Dec 2015 \\ Faculty Reviews are review articles written by the prestigious Members of Faculty Opinions. The articles are commissioned and peer reviewed before publication to ensure that the final, published version is comprehensive and accessible. The reviewers who approved the final version are listed with their names and affiliations.}

\footnotetext{
1. Albert Reynolds, Vanderbilt University

Medical Center, Nashville, USA

2. David Sherwood, Duke University, Durham, USA

3. Carien Niessen, University of Cologne,

Cologne, Germany

Any comments on the article can be found at the end of the article.
} 
Corresponding author: Jeff Hardin (jdhardin@wisc.edu)

Competing interests: The author declares that he has no competing interests.

Grant information: This work was supported by National Institutes of Health grants R01GM58038 and R21HD072769. I apologize to many fine colleagues, whose work I could not cover at the level of detail it deserves, especially as it relates to work outside of C. elegans.

Copyright: @ 2015 Hardin J. This is an open access article distributed under the terms of the Creative Commons Attribution License, which permits unrestricted use, distribution, and reproduction in any medium, provided the original work is properly cited.

How to cite this article: Hardin J. Getting to the core of cadherin complex function in Caenorhabditis elegans [version 1; peer review: 3 approved] F1000Research 2015, 4(F1000 Faculty Rev):1473 https://doi.org/10.12688/f1000research.6866.1

First published: 18 Dec 2015, 4(F1000 Faculty Rev):1473 https://doi.org/10.12688/f1000research.6866.1 


\section{Caenorhabditis elegans: a simple system for studying cadherins}

The classic cadherin-catenin complex (CCC) is a conserved multiprotein complex found in all metazoans and connects transmembrane cadherins to the actin cytoskeleton ${ }^{1}$. This strong yet dynamic connection is made possible by linker proteins known as catenins. $\beta$-catenin binds the cytoplasmic tail of classic cadherins and binds $\alpha$-catenin, which in turn binds F-actin. In epithelial tissues in situ, the CCC localizes to adherens junctions, which confer adhesive connections between cells and which allow cells to exert forces across epithelia ${ }^{2}$. In addition, cell-cell contacts must withstand the stresses generated by actomyosin-mediated contractility ${ }^{3}$. The importance of fundamental work in vertebrate tissue culture for understanding the $\mathrm{CCC}$ is well documented and has provided many insights into CCC function. In living organisms, however, the CCC must function in three dimensions and must be tightly regulated. Perhaps the most dramatic example of the need for such regulation is in developing embryos, where cells must make and break cell-cell contacts in a tightly coordinated fashion to build new tissues. Analyzing CCC function in these more complicated tissue environments is challenging; it requires an ability to manipulate key aspects of CCC function while analyzing the detailed cellular effects of such manipulations in vivo.

The nematode $C$. elegans is a powerful tool for in vivo analysis of CCC function ${ }^{4}$. C. elegans epithelia possess a bona fide adherens junctional complex (4,5; Figure $1 \mathrm{~A}, \mathrm{~B})$, which possesses a single classic cadherin, HMR-1; the short isoform, HMR-1A, forms a complex with HMP- $1 / \alpha$-catenin and HMP- $2 / \beta$-catenin ${ }^{6}$ and is bound by the p120ctn homologue, JAC-1, at its juxtamembrane region ${ }^{7}$. Two key events, driven by morphogenetic movements in the epidermis, critically depend on the CCC. Zygotic loss of function of the cadherin, HMR-1, leads to the Hammerhead phenotype, in which epidermal cells fail to enclose the embryo. Zygotic loss of HMP-1/ $\alpha$-catenin or HMP-2/ $\beta$-catenin does not lead to enclosure failure, because maternally provided mRNA allows homozygous embryos to complete enclosure. Instead, as the embryo tries to elongate via a coordinated change in shape of its cells from a cuboidal shape to being elongated roughly fourfold along the anterior-posterior axis (reviewed in 8), F-actin-based circumferential filament bundles (CFBs) detach from junctions, leading to the Humpback phenotype. CFB detachment is accompanied by loss or tearing (or both) of the junctional proximal actin network recruited by HMP- $1^{6}$.

Remarkably, other earlier embryonic events, such as cleavage and gastrulation, while modulated by CCC function, can proceed without them. The relatively mild resulting phenotypes have actually provided advantages for identifying molecular pathways that act alongside the CCC during cleavage and gastrulation ${ }^{9,10}$. During later morphogenesis, the use of weak hmp-1 and hmp-2 mutants has similarly made genome-wide RNA interference (RNAi) screens possible to identify molecular components that act with or alongside the $\mathrm{CCC}$ during morphogenesis ${ }^{1-14}$. This brief review discusses recent work that sheds additional light on the core components of the CCC in C. elegans, how the CCC is deployed in the early embryo, and how it is localized during epithelial tissue remodeling.

\section{A conserved phosphorylation switch controls the cadherin/ $\beta$-catenin interaction}

C. elegans is a useful model system for pursuing a structurefunction approach to study the CCC. By rescuing strong loss-offunction mutants with green fluorescent protein (GFP)-tagged transgenes, it has been possible to assess several key aspects of CCC function in a living organism. For example, the $\mathrm{N}$-terminal domain of HMP-1/ $\alpha$-catenin, which binds HMP- $2 / \beta$-catenin, has been shown to be crucial for recruitment of HMP-1 to junctions, and the $\mathrm{C}$ terminus, which binds $\mathrm{F}$-actin, is necessary for all key functions of HMP- $1^{15}$, vetting results from prior work in tissue culture (reviewed in 16) and consistent with similar recent work in Drosophila ${ }^{17}$.

Because of the mechanical stress experienced by the C. elegans epidermis during elongation, its morphogenesis requires robust cell-cell adhesion. However, adhesion in embryos must also be dynamically regulated as cell-cell contacts are extensively remodeled during these processes. One possible mechanism for regulation of CCC components is phosphorylation. Studies in cell culture have revealed that a serine-rich region of the cadherin tail is phosphorylated $^{18}$, and in vitro phosphorylation of the cadherin tail strengthens its affinity for $\beta$-catenin by about 800 fold $^{19-21}$. Mutation of the phosphorylated serines in the cadherin tail reduces cellcell adhesion when these constructs are introduced into NIH 3T3 cells $^{20}$. McEwen et al. recently narrowed these phosphorylation sites to three residues that are required for high-affinity $\beta$-catenin binding and cell adhesion in cultured cells ${ }^{22}$. In contrast, phosphorylation of $\beta$-catenin by Src at Tyr654 reduces affinity for cadherin ${ }^{23}$, and CKII phosphorylation of $\beta$-catenin regulates its interaction with $\alpha$-catenin ${ }^{24}$.

Recent work by Choi et al. ${ }^{25}$ rigorously tests the importance of phosphorylation of the cadherin cytoplasmic tail and $\beta$-catenin in C. elegans. As with vertebrate E-cadherin, phosphorylation of the HMR-1/cadherin tail dramatically increases its affinity for HMP-2/ $\beta$-catenin. Solving the structure of an HMR-1/HMP-2 co-crystal reveals that a key conserved serine, S1212, which appears in the structure only when it is phosphorylated, is positioned precisely to allow interaction with several key residues in HMP-2 (Figure 1C). In some conformations, three additional downstream residues (T1215, S1218, and S1221) are phosphorylated. HMR-1 S1212 and S1218 are equivalent to two of the three residues which have been recently identified as bearing the majority of vertebrate E-cadherin phosphorylation and which have been proposed to be sequentially phosphorylated in tissue culture ${ }^{22}$. Significantly, S1212 and downstream residues are phosphorylated in vivo as well, based on results of co-immunoprecipitation/mass spectrometry analysis performed by Callaci et $a l .{ }^{26}$. Independent assessment of binding affinities via reconstitution on liposomes confirms the work of Choi et al. showing that S1212 is crucial for HMR-1/HMP-2 association $^{26}$.

The ideal test of necessity, of course, is in vivo requirement. Choi et al. found that a full-length $h m r-1: \because g f p$ transgene driven by the endogenous promoter rescues $h m r-1$ deletion mutants to viability but that a non-phosphorylatable HMR-1::GFP S1212A construct cannot, despite localizing to junctions ${ }^{25}$. Although it is difficult to 

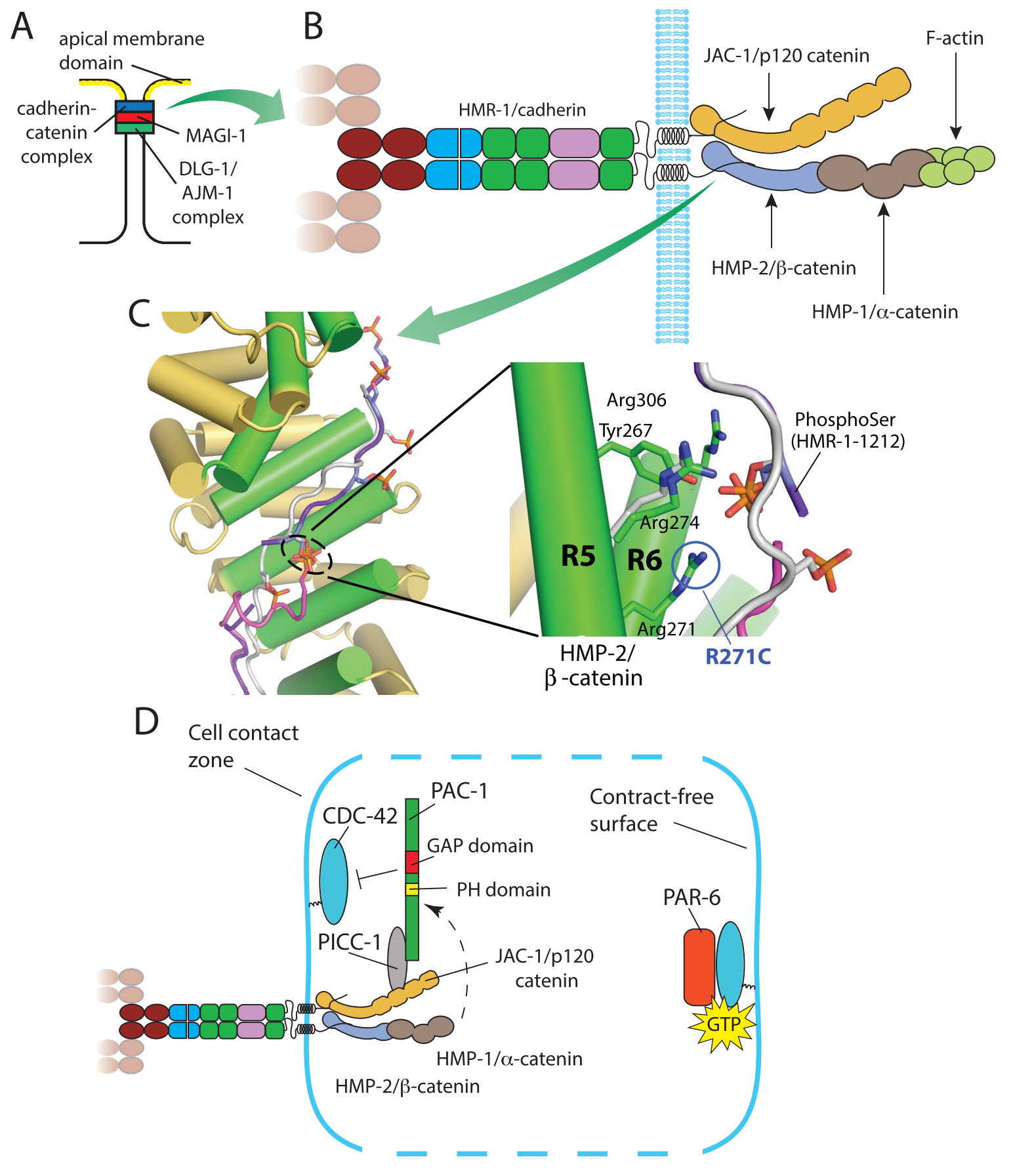

Figure 1. The classic cadherin-catenin complex (CCC) in Caenorhabditis elegans is a key regulator of morphogenesis and cell polarity. (A) Schematic of the $C$. elegans apical junction. MAGI-1 (membrane-associated guanylate kinase with inverted organization protein 1) localizes to a domain between the CCC and the DLG-1/AJM-1 complex. (B) The core components of the CCC. HMR-1A is the epithelial cadherin, HMP-2 the junctional $\beta$-catenin, HMP-1 the C. elegans $\alpha$-catenin, and JAC-1 the p120ctn homolog. (C) Structures of HMP-2 (Armadillo repeats shown in gold and green) bound to the phosphorylated HMR-1 cytoplasmic domain (magenta). The structure of phosphorylated E-cadherin cytoplasmic domain bound to $\beta$-catenin is also shown superimposed on the structure (gray; PDB ID: 1I7W). Phosphoserine 1212 in HMR-1 interacts with residues in HMP-2, including R271, which is mutated to C in the canonical hmp-2 allele, zu364. (D) A model for cadherin-induced cell polarization in blastomeres in the $C$. elegans embryo, based on 41. PAC-1 is recruited via CCC components to cell contact sites, where its GTPase-activating protein (GAP) domain negatively regulates CDC-42 at cell contacts to inhibit recruitment of PAR-6. The dashed line indicates a role that may not be direct. An inferred function that acts independently of the CCC via the pleckstrin-homology $\mathrm{PH}$ ) domain of PAC-1 is not shown for clarity. $\mathbf{A}$ is adapted from 13 with permission. $\mathbf{B}$ is adapted from 63 with permission. $\mathbf{C}$ is adapted with permission from a figure courtesy of Hee-Jung Choi by using data from 25. 
show that sequential phosphorylation actually occurs in vivo, Choi et al. assessed the possibility that pS1212 acts as a priming site for downstream phosphorylations by creating an $\mathrm{hmr}-1(\mathrm{T12} 15 \mathrm{~A}$, S1218A)::gfp construct in which S1212 remains phosphorylatable, but the C-terminal phosphorylation cascade is blocked. This construct is able to partially rescue $h m r-1$ (zu389) embryonic lethality but cannot rescue larval lethality, indicating that, although S1212 is a key phosphoswitch, other phosphosites also have some importance.

In addition to examining the cadherin cytoplasmic tail, Choi et al. examined key residues in HMP-2/ $\beta$-catenin. A gratifying result of this analysis was that sequencing of a canonical strong $h m p-2$ allele (zu364) revealed that one of the coordinating residues in HMP-2 visible in the HMR-1/HMP-2 co-crystal, Arg271, is mutated to a cysteine (Figure 1C). Since previous in vitro work had shown that Src phosphorylation of vertebrate $\beta$-catenin at Tyr654 reduces its affinity for E-cadherin ${ }^{23}$, Choi et $a l .{ }^{25}$ mutated the equivalent residue in HMP-2, Tyr599, to create phosphomimetic and phospho-null mutations. They found that both constructs were able to rescue $h m p-2(z u 364)$ to viability and almost as efficiently as wild-type constructs, although the distribution of the phosphomimetic (predicted to have weaker binding to cadherin) becomes punctate and appears to cluster near sites where CFBs insert orthogonally into the junctional-proximal actin network. This suggests that the CCC in such embryos may be more susceptible to mechanical tension during morphogenesis, since CFBs are thought to transmit tension throughout the epidermis ${ }^{8}$.

In addition to the sites identified in the work of Choi et al., Callaci et al. found phosphosites in HMP-2 and HMP-1 in embryonic extracts. In vitro, HMP-2 protein harboring phosphomimetic mutations at the sites identified from extracts reduced its affinity for HMR-1. In vivo, constructs carrying identical phosphomimetic mutations rescue, but somewhat more weakly than wild-type transgenes. In contrast, perturbations of phosphosites identified in HMP-1 from embryonic extracts did not affect the ability of HMP-1 to bind actin or its comformation ${ }^{26}$. These results are similar to those in vertebrate tissue culture and Drosophila, which found only weak effects of numerous phosphosites in $\alpha$-catenin ${ }^{27}$.

Taken together, these results demonstrate the fruitfulness of an "angstroms to embryos" approach in C. elegans (i.e., correlation of changes in single residues identified as important from detailed molecular structural studies with aggregate effects on embryogenesis). There are several limitations to this approach, however. First, it leaves an important "meso-level" analysis of CCC function, such as the role of subcellular mechanics, largely unexplored (e.g., 28). Second, basic structure-function studies cannot address dynamic phosphorylation and dephosphorylation events. It remains to be seen whether such dynamic events can fine-tune CCC function or whether the functionally important sites identified in these studies are constitutively phosphorylated.

\section{The PAR/aPKC complex as an upstream regulator of the CCC}

There is abundant evidence that cadherin localization in metazoan epithelia is heavily influenced by molecular pathways that establish and maintain apicobasal polarity. In particular, polarity crucially depends on the function of the PAR/aPKC complex ${ }^{29-31}$. PAR proteins PAR-3 and PAR-6 were originally discovered in C. elegans through their maternal role in partitioning components in the one-cell zygote ${ }^{32}$. Subsequent work in worms, Drosophila, and tissue culture added molecular players and further clarified the role of this important complex in the establishment of cell polarity. A conserved cassette includes activated Cdc42, which binds Par6, which in turn recruits aPKC. Par3 (Bazooka in Drosophila) and $\mathrm{Cdc} 42 / \mathrm{Par} 6 / \mathrm{aPKC}$ engage in a complicated interplay at the apical ends of cells in many contexts (reviewed in 29,31,33-35).

Recent work in C. elegans has added insight into PAR/aPKC function, especially as it relates to $\mathrm{CCC}$ function. Previous work had shown that during $C$. elegans intestinal differentiation, CCC and polarity complex proteins colocalize to foci that accumulate at the apical surface ${ }^{36,37}$, eventually coalescing to form bona fide junctions. Examining the role of the PAR/aPKC complex during this process was made possible by using maternally provided, modified PAR-3 and PAR- 6 proteins that are present during polarization of the onecell zygote but that are rapidly degraded thereafter ${ }^{37}$. Curiously, in the absence of PAR-3, intestinal HMR-1 is initially mislocalized, but HMP-1 is still present in foci ${ }^{36}$ that now localize with the more basal junctional component, DLG-1/Discs large ${ }^{38}$. Similar localization defects are seen in the pharynx in par-3 mutants ${ }^{36}$. Although par-3 function is initially dispensable in the epidermis, apical localization of HMR-1 and DLG-1 is progressively lost and the epidermis eventually tears ${ }^{36}$. In both the intestine and the epidermis, PAR-6 is required for junctional maturation but not for targeting of the CCC to initial spot junctions ${ }^{37}$. This result is largely consonant with similar previous work in Drosophila showing that the relationship between Par3 and Par6 is complex. There, Par3/Bazooka is initially upstream of Par6, but later Par3 and Par6/aPKC become spatially separated (reviewed in 35).

Recent work on the $C$. elegans pharynx extends previous work by showing that PAR-6 is necessary for polarization of arcade cells ${ }^{39}$. HMR-1/cadherin, the ERM protein, ERM-1, and the DLG-1/Discs large binding partner, AJM-1, all fail to localize in par-6(M/Z) embryos. In contrast to the crucial requirement for par- 6 function, embryos knocked down for $h m r-1 /$ cadherin and pat-3/ $\beta$-integrin do not show major defects in localization of apical proteins, suggesting that neither the CCC nor adhesion to the basal lamina is essential for apical polarization in arcade cells. In the future, identifying other cell adhesion pathways that act in the absence of these two crucial adhesion systems should yield insights into how epithelia regulate polarity downstream of the PAR/aPKC system in metazoa.

\section{The CCC as a reciprocal regulator of the PAR/aPKC complex in blastomeres}

The relationship between the CCC and the PAR/aPKC proteins, based on the work described thus far, is admittedly somewhat complex in detail but comports well with work in many other systems, in which the PAR/aPKC complex acts upstream of the CCC in epithelial polarization (reviewed in 29,31,33). It is surprising, then, that the PAR/aPKC complex is not essential for blastomere adhesion in the early embryo ${ }^{38}$. This lack of absolute requirement, however, has proven to be an advantage for teasing apart the 
complex interplay between the CCC and the PAR/aPKC complex during embryogenesis. To gain insight into how blastomere polarity is established, Anderson et al. ${ }^{40}$ screened for mutations that prevent the normal localization pattern of PAR-6::GFP, which is confined to the outer (non-contact) surfaces of blastomeres in early $C$. elegans embryos. They identified PAC-1 (ARHGAP21 in humans), a Rhofamily GTPase-activating protein (GAP). PAR-6, PAR-3, and aPKC/PKC-3 all show a symmetric cortical localization in pac-1 blastomeres. As in embryos with M/Z loss of PAR proteins, pac-1 mutant embryos show delayed ingression of cells during gastrulation but no defects in epithelial polarity in the later embryo, suggesting that PAC-1 is dispensable for other types of PAR asymmetries. GFP::PAC-1 localizes to inner (contact) surfaces but not the outer surfaces of blastomeres (i.e., in a pattern complementary to PAR-6). The complementary distributions of PAR-6 and PAC-1 suggest that PAC- 1 controls PAR-6 localization by inhibiting CDC-42 at contact surfaces between blastomeres. This supposition was confirmed by making mutant PAR- 6 protein that cannot bind CDC-42. The mutant protein mislocalizes, indicating that activated CDC-42 leads to recruitment of PAR-6, whereas PAC-1 at cell-cell contacts prevents PAR- 6 accumulation there through downregulation of $\mathrm{CDC}-42^{40}$

Recent work from the Nance group extends this PAC-1/ARHGAP21 story $^{41}$. Given that PAC-1 localizes to the same sites in the early embryo where the CCC is found, Klompstra et al. ${ }^{41}$ examined the distribution of full-length PAC-1 in $h m r-1 /$ cadherin loss-of-function embryos and found that it is reduced, although its localization is not abolished. N-terminal fragments of PAC-1 completely fail to localize in $h m r-1$ mutants, indicating that this region of the protein is regulated by the CCC. Deleting the pleckstrin-homology $(\mathrm{PH})$ domain of PAC-1 abolished this residual PAC-1 in hmr-l mutant embryos, indicating that this domain is required for the putative redundant localization mechanism. Taken together, these results suggest that both the $\mathrm{CCC}$ and other unidentified mechanisms localize PAC-1 to contact sites between blastomeres.

Klompstra et al. then examined the catenins. Loss of jac-1/p120ctn function led to partial loss of GFP-PAC-1N from cell contacts. Removing HMP-1 in jac-1 embryos caused a complete loss of GFP-PAC-1N from contacts, as in $h m r-1$ embryos; these results suggest that JAC-1 and HMP-1 may work together in localizing PAC-1. Yeast two-hybrid screening eventually identified a possible mechanism linking PAC-1 and JAC-1 involving PICC-1 (PAC-1interacting coiled-coil protein 1), the homologue of a poorly characterized human coiled-coil protein known as CCDC85B/DIPA, which has been shown to bind p120 $\mathrm{ctn}^{42}$. GFP::PICC-1 localizes in an HMR-1- and JAC-1-dependent manner but persists in hmp-1(RNAi) embryos. Taken together, these data suggest a model in which PAC-1 is localized to cell surfaces in contact via both JAC-1/PICC-1 and HMP-1 (Figure 1D). To test this CCCdependent model for Cdc42/PAR polarization, Klompstra et al. forced expression of the HMR-1 cytoplasmic tail ubiquitously at the cell surface by using a PH-domain chimera. The result was loss of polarization and greatly reduced PAR- 6 at the cortex. These studies suggest a model whereby CCC-dependent contact between blastomeres leads to localized downregulation of $\mathrm{Cdc} 42$ via PAC-1/ARHGAP21 (Figure 1D).
The findings of Klompstra et al. may also help to explain puzzling results from the previous literature. As stated above, phenotypes associated with loss of function of the single p120ctn family member in both flies and worms are remarkably mild, given the clearly essential roles that $\mathrm{p} 120 \mathrm{ctn}$ plays in vertebrates ${ }^{43-46}$. One potential explanation for this discrepancy is that the $\delta$-catenin $/ \mathrm{p} 120 \mathrm{ctn}$ gene family in vertebrates has apparently arisen because of gene duplication from a single ancestral gene that encoded a protein more similar to $\delta$-catenin. Subsequently, a gene encoding p120ctn arose in vertebrates, which has evolved essential roles in numerous processes (reviewed in 47). The work of Klompstra et al. may have uncovered an ancestral role for $\mathrm{p} 120 \mathrm{ctn} / \delta$-catenin in spatial control of GAPs for Rho family GTPases. These findings comport well with previous studies of p120ctn, which have implicated it in recruitment of p190RhoGAP to junctions ${ }^{48-51}$. However, in worms, the role of PAC-1 is modulatory, since loss of pac-1 function is not lethal on its own (40 and Jeff Hardin and Allison Lynch, unpublished data).

\section{The AP-1 complex regulates localization of the CCC during tissue remodeling}

In addition to regulation of the core components of the cadherin/ catenin complex by phosphorylation and through interactions with the partitioning-defective (PAR)/atypical protein kinase $\mathrm{C}$ (aPKC) polarity system, a well-known regulatory node affecting the CCC is intracellular trafficking. Here again, much of this work has been done in cultured cells (reviewed in 52-54); C. elegans has promise as a system for examining what aspects of trafficking of CCC components to and from the plasma membrane are essential in a metazoan. Some previous results have been surprising in the context of endocytic recycling of cadherins. For example, p120ctn has been shown to regulate endocytic trafficking of VE-cadherin by masking a conserved motif in its cytoplasmic tail ${ }^{55}$. If such regulation occurs in the case of HMR-1/cadherin in C. elegans, it must only be modulatory, given the mild phenotypes observed in the absence of JAC-1/p120 $\mathrm{ctn}^{7,41}$. Similar results have been obtained in Drosophila, in which very mild phenotypes have been reported under laboratory conditions following p120ctn loss of function ${ }^{56,57}$. The AP-2 clathrin adaptor complex is likewise surprisingly dispensable in C. elegans ${ }^{58,59}$, although loss of AP-2 components has been reported to lead to synergistic lethality in a weak $h m p-1 / \alpha$-catenin mutant background in a genome-wide RNAi screen ${ }^{13}$.

Work from the Michaux group ${ }^{60}$ has shown that, in contrast to the AP-2 complex, which is involved in endocytic recycling, the clathrin adaptor protein complex 1 (AP-1), well known to be involved in the export of proteins to the plasma membrane, is required for normal apicobasal polarity in the embryonic intestine of C. elegans. Knockdown of AP-1 subunits leads to homogeneous distribution of apical and basally localized proteins, including, significantly, PAR/aPKC complex proteins and CDC-42. Interestingly, knockdown embryos have ectopic lumenal vesicles, including components of both the CCC and the more basal complex that contains the C. elegans homologue of Discs large, DLG-1, and its binding partner, AJM-1 ${ }^{60}$.

Recent work by the Michaux group ${ }^{61}$ extends this work on AP-1 to the $C$. elegans epidermis. To identify genes required for polarized localization of HMR-1 in the epidermis, Gillard et al. ${ }^{61}$ used RNAi 
of candidate genes to identify genes whose knockdown led to lateral mislocalization of HMR-1. These included chc-1/clathrin heavy chain, the $\sigma$ and $\gamma$ subunits of AP-1 complex (aps-1 and apg-1), the functionally redundant AP-1 $\mu$ subunits, and the AP-1-interacting protein HEATR5B/p200/Laa1p (in C. elegans known as soap-1, for sorting of apical proteins). In contrast, depletion of dynamin, RAB-5, RAB-11, or exocyst complex components led to changes in overall levels of HMR-1 but not its apicobasal localization. Thus, although these proteins play an essential role in HMR-1 secretion or recycling (or both) at the apical membrane, they-unlike AP-1 components-are not involved in apicobasal polarity. Gillard et al. went on to examine interactions among AP-1, clathrin subunits, and SOAP-1. Loss of AP-1 led to a strong decrease in recruitment of clathrin subunits to membranes. Similarly, loss of SOAP-1 led to an overall reduction in AP-1 components, suggesting that SOAP-1 is involved in targeting of AP-1 to sites of protein export to the membrane.

Additional observations, however, suggest that there are more global disruptions in apicobasal polarization in epidermal cells following loss of AP-1 components that include, but are not restricted to, the CCC. RNAi against the $\sigma, \gamma$, or both $\mu$ subunits of AP-1 induces a shift in the position of the DLG-1/AJM-1 complex to a more lateral position. In addition, in normal embryos, a small amount of HMR-1/cadherin is visible in the lateral membrane, but this lateral cadherin disappears during subsequent morphogenesis as the embryo elongates. In contrast, in aps-1(RNAi) embryos, HMR-1 accumulates laterally. Given the crucial role of the CCC during morphogenesis, this leads to disruption of F-actin during elongation. How the AP-1 is distinctively involved in maintenance of apicobasal polarity remains unclear.

Taken together, the findings of Gillard et al. also raise interesting questions regarding the selectivity of effects of perturbing the AP-1 complex and other apicobasal cues in various epithelia in C. elegans. The specific mislocalization of HMR-1 in the epidermis, for example, contrasts markedly with the effects of depletion of AP-1 component in the intestine, in which no such mislocalization is observed. Previous work on the PAR complex similarly showed differential requirements in different tissues. While PAR-3 is critical for $\mathrm{CCC}$ establishment in the intestine, it is surprisingly dispensable in the epidermis, although localization of HMR-1 and DLG-1 is eventually lost, along with the mechanical integrity of the epidermis (36; reviewed in 62). What might account for such differences? The answer is unclear, but a key difference between the intestine and epidermis is the presence of a cuticle in the latter. Identifying molecular differences in CCC trafficking and apicobasal polarization in these tissues will be interesting in the future.

\section{Conclusions}

C. elegans is a useful system for studying both the core functions and regulation of the $\mathrm{CCC}$. On the one hand, the rapidity with which the function of single amino acids within each of the core CCC proteins can be assessed has allowed incisive experiments to be performed that link single amino acid changes in CCC proteins to essential, highly specific morphogenetic processes. On the other hand, the surprising lack of stringent requirements for CCC components or their modifiers in some developmental events has provided an opportunity to uncover conserved pathways shared by all metazoans. There is every reason to expect $C$. elegans to continue to be a useful model system for analyzing the CCC in the future.

\section{Abbreviations}

AP-1, clathrin adaptor protein complex 1; aPKC, atypical protein kinase $\mathrm{C}$; $\mathrm{CCC}$, cadherin-catenin complex; $\mathrm{CFB}$, circumferential filament bundle; GAP, GTPase-activating protein; GFP, green fluorescent protein; PAR, partitioning-defective; $\mathrm{PH}$, pleckstrinhomology; RNAi, RNA interference; SOAP-1, sorting of apical proteins-1.

\section{Competing interests}

The author declares that he has no competing interests.

\section{Grant information}

This work was supported by National Institutes of Health grants R01GM58038 and R21HD072769. I apologize to many fine colleagues, whose work I could not cover at the level of detail it deserves, especially as it relates to work outside of C. elegans.
1. Takeichi $M$ : Dynamic contacts: rearranging adherens junctions to drive epithelial remodelling. Nat Rev Mol Cell Biol. 2014; 15(6): 397-410. PubMed Abstract | Publisher Full Text

2. Harris TJ, Tepass U: Adherens junctions: from molecules to morphogenesis Nat Rev Mol Cell Biol. 2010; 11(7): 502-14. PubMed Abstract | Publisher Full Text

3. Lecuit T, Yap AS: E-cadherin junctions as active mechanical integrators in tissue dynamics. Nat Cell Biol. 2015; 17(5): 533-9. PubMed Abstract | Publisher Full Text

4. Hardin J, Lynch A, Loveless T, et al:: Cadherins and their partners in the nematode worm Caenorhabditis elegans. Prog Mol Biol Transl Sci. 2013; 116 239-62.

PubMed Abstract | Publisher Full Text

5. Lynch AM, Hardin J: The assembly and maintenance of epithelial junctions in C. elegans. Front Biosci (Landmark Ed). 2009; 14: 1414-32. PubMed Abstract | Publisher Full Text | Free Full Text
F Costa M, Raich W, Agbunag C, et al.: A putative catenin-cadherin system mediates morphogenesis of the Caenorhabditis elegans embryo. J Cell Biol. 1998; 141(1): 297-308.

PubMed Abstract | Publisher Full Text | Free Full Text | F1000 Recommendation

7. Pettitt J, Cox EA, Broadbent ID, et al.: The Caenorhabditis elegans p120 catenin homologue, JAC-1, modulates cadherin-catenin function during epidermal morphogenesis. J Cell Biol. 2003; 162(1): 15-22. PubMed Abstract | Publisher Full Text | Free Full Text

8. Chisholm AD, Hardin J: Epidermal morphogenesis. WormBook. 2005; 1-22. PubMed Abstract | Publisher Full Text

9. F Grana TM, Cox EA, Lynch AM, et al:: SAX-7/L1CAM and HMR-1/cadherin function redundantly in blastomere compaction and non-muscle myosin accumulation during Caenorhabditis elegans gastrulation. Dev Biol. 2010; 344(2): 731-44.

PubMed Abstract | Publisher Full Text | Free Full Text | F1000 Recommendation 
10. F Sawyer JM, Glass S, Li T, et al.: Overcoming redundancy: an RNAi enhancer screen for morphogenesis genes in Caenorhabditis elegans. Genetics. 2011; 188(3): 549-64.

PubMed Abstract | Publisher Full Text | Free Full Text | F1000 Recommendation

11. Cox-Paulson EA, Walck-Shannon E, Lynch AM, et al.: Tropomodulin protects $\alpha$-catenin-dependent junctional-actin networks under stress during epithelial morphogenesis. Curr Biol. 2012; 22(16): 1500-5. PubMed Abstract | Publisher Full Text | Free Full Text

12. F Lockwood C, Zaidel-Bar R, Hardin J: The C. elegans zonula occludens ortholog cooperates with the cadherin complex to recruit actin during morphogenesis. Curr Biol. 2008; 18(17): 1333-7. PubMed Abstract | Publisher Full Text | Free Full Text | F1000 Recommendation

13. Lynch AM, Grana T, Cox-Paulson E, et al:: A genome-wide functional screen shows MAGI-1 is an L1CAM-dependent stabilizer of apical junctions in C. elegans. Curr Biol. 2012; 22(20): 1891-9. PubMed Abstract | Publisher Full Text | Free Full Text

14. F Zaidel-Bar R, Joyce MJ, Lynch AM, et al.: The F-BAR domain of SRGP-1 facilitates cell-cell adhesion during $C$. elegans morphogenesis. J Cell Biol. 2010; 191(4): 761-9.

PubMed Abstract | Publisher Full Text | Free Full Text | F1000 Recommendation

15. F Kwiatkowski AV, Maiden SL, Pokutta S, et al:: In vitro and in vivo reconstitution of the cadherin-catenin-actin complex from Caenorhabditis elegans. Proc Natl Acad Sci U S A. 2010; 107(33): 14591-6. PubMed Abstract | Publisher Full Text | Free Full Text | F1000 Recommendation

16. Maiden SL, Hardin J: The secret life of $\alpha$-catenin: moonlighting in morphogenesis. J Cell Biol. 2011; 195(4): 543-52.

PubMed Abstract | Publisher Full Text | Free Full Text

17. F Desai R, Sarpal R, Ishiyama N, et al.: Monomeric $\alpha$-catenin links cadherin to the actin cytoskeleton. Nat Cell Biol. 2013; 15(3): 261-73. PubMed Abstract | Publisher Full Text | F1000 Recommendation

18. Stappert J, Kemler R: A short core region of E-cadherin is essential for catenin binding and is highly phosphorylated. Cell Adhes Commun. 1994; 2(4): 319-27. PubMed Abstract | Publisher Full Text

19. F Choi HJ, Huber AH, Weis WI: Thermodynamics of beta-catenin-ligand interactions: the roles of the $\mathrm{N}$ - and $\mathrm{C}$-terminal tails in modulating binding affinity. J Biol Chem. 2006; 281(2): 1027-38.

PubMed Abstract | Publisher Full Text | F1000 Recommendation

20. F Lickert H, Bauer A, Kemler R, et al.: Casein kinase II phosphorylation of $\mathrm{E}$-cadherin increases $\mathrm{E}$-cadherin/beta-catenin interaction and strengthens cell-cell adhesion. J Biol Chem. 2000; 275(7): 5090-5.

PubMed Abstract | Publisher Full Text | F1000 Recommendation

21. F Huber $\mathrm{AH}$, Weis WI: The structure of the beta-catenin/E-cadherin complex and the molecular basis of diverse ligand recognition by beta-catenin. Cell. 2001; 105(3): 391-402

PubMed Abstract | Publisher Full Text | F1000 Recommendation

22. $\mathrm{F}$ McEwen $\mathrm{AE}$, Maher MT, Mo R, et al.: E-cadherin phosphorylation occurs during its biosynthesis to promote its cell surface stability and adhesion. $\mathrm{Mol}$ Biol Cell. 2014; 25(16): 2365-74

PubMed Abstract | Publisher Full Text | Free Full Text | F1000 Recommendation

23. Roura S, Miravet S, Piedra J, et al.: Regulation of E-cadherin/Catenin association by tyrosine phosphorylation. J Biol Chem. 1999; 274(51): 36734-40. PubMed Abstract | Publisher Full Text

24. Bek S, Kemler R: Protein kinase CKII regulates the interaction of beta-catenin with alpha-catenin and its protein stability. J Cell Sci. 2002; 115(Pt 24): 4743-53. PubMed Abstract | Publisher Full Text

25. Choi HJ, Loveless T, Lynch AM, et al:: A conserved phosphorylation switch controls the interaction between cadherin and $\beta$-catenin In vitro and in vivo. Dev Cell. 2015; 33(1): 82-93.

PubMed Abstract | Publisher Full Text | Free Full Text

26. Callaci S, Morrison K, Shao X, et al:: Phosphoregulation of the C. elegans cadherin-catenin complex. Biochem J. 2015; 472(3): 339-52. PubMed Abstract | Publisher Full Text | Free Full Text

27. Escobar DJ, Desai R, Ishiyama N, et al:: $\alpha$-Catenin phosphorylation promotes intercellular adhesion through a dual-kinase mechanism. J Cell Sci. 2015 128(6): 1150-65.

PubMed Abstract | Publisher Full Text | Free Full Text

28. Budnar S, Yap AS: A mechanobiological perspective on cadherins and the actin-myosin cytoskeleton. F1000Prime Rep. 2013; 5: 35

PubMed Abstract | Publisher Full Text | Free Full Text

29. F Goldstein B, Macara IG: The PAR proteins: fundamental players in anima cell polarization. Dev Cell. 2007; 13(5): 609-22.

PubMed Abstract | Publisher Full Text | Free Full Text | F1000 Recommendation

30. F Nance J: Getting to know your neighbor: cell polarization in early embryos. J Cell Biol. 2014; 206(7): 823-32.

PubMed Abstract | Publisher Full Text | Free Full Text | F1000 Recommendation

31. F Nance J, Zallen JA: Elaborating polarity: PAR proteins and the cytoskeleton. Development. 2011; 138(5): 799-809.

PubMed Abstract | Publisher Full Text | Free Full Text | F1000 Recommendation

32. Kemphues KJ, Priess JR, Morton DG, et al.: Identification of genes required for cytoplasmic localization in early C. elegans embryos. Cell. 1988; 52(3): 311-20. PubMed Abstract | Publisher Full Text

33. St Johnston D, Ahringer J: Cell polarity in eggs and epithelia: parallels and diversity. Cell. 2010; 141(5): 757-74.

PubMed Abstract | Publisher Full Text

34. Vorhagen S, Niessen CM: Mammalian aPKC/Par polarity complex mediated regulation of epithelial division orientation and cell fate. Exp Cell Res. 2014; 328(2): 296-302.

PubMed Abstract | Publisher Full Text

35. Tepass U: The apical polarity protein network in Drosophila epithelial cells: regulation of polarity, junctions, morphogenesis, cell growth, and survival. Annu Rev Cell Dev Biol. 2012; 28: 655-85. PubMed Abstract | Publisher Full Text

36. F Achilleos A, Wehman AM, Nance J: PAR-3 mediates the initial clustering and apical localization of junction and polarity proteins during $C$. elegans intestinal epithelial cell polarization. Development. 2010; 137(11): 1833-42. PubMed Abstract | Publisher Full Text | Free Full Text | F1000 Recommendation

37. $F$ Totong $R$, Achilleos A, Nance J: PAR- 6 is required for junction formation but not apicobasal polarization in C. elegans embryonic epithelial cells. Development. 2007; 134(7): 1259-68.

PubMed Abstract | Publisher Full Text | F1000 Recommendation

38. F Nance J, Munro EM, Priess JR: C. elegans PAR-3 and PAR-6 are required for apicobasal asymmetries associated with cell adhesion and gastrulation. Development. 2003; 130(22): 5339-50.

PubMed Abstract | Publisher Full Text | F1000 Recommendation

39. F Von Stetina SE, Mango SE: PAR-6, but not E-cadherin and $\beta$-integrin, is necessary for epithelial polarization in C. elegans. Dev Biol. 2015; 403(1): 5-14. PubMed Abstract | Publisher Full Text | Free Full Text | F1000 Recommendation

40. F Anderson DC, Gill JS, Cinalli RM, et al.: Polarization of the C. elegans embryo by RhoGAP-mediated exclusion of PAR-6 from cell contacts. Science. 2008; 320(5884): 1771-4.

PubMed Abstract | Publisher Full Text | Free Full Text | F1000 Recommendation

41. F Klompstra D, Anderson DC, Yeh JY, et al:: An instructive role for C. elegan E-cadherin in translating cell contact cues into cortical polarity. Nat Cell Biol. 2015; 17(6): 726-35.

PubMed Abstract | Publisher Full Text | Free Full Text | F1000 Recommendation

42. Markham NO, Doll CA, Dohn MR, et al:: DIPA-family coiled-coils bind conserved soform-specific head domain of p120-catenin family: potential roles in hydrocephalus and heterotopia. Mol Biol Cell. 2014; 25(17): 2592-603. PubMed Abstract | Publisher Full Text | Free Full Text

43. Pieters $\mathrm{T}$, van Hengel J, van Roy F: Functions of p120ctn in development and disease. Front Biosci (Landmark Ed). 2012; 17: 760-83. PubMed Abstract | Publisher Full Text

44. Kourtidis A, Ngok SP, Anastasiadis PZ: p120 catenin: an essential regulator of cadherin stability, adhesion-induced signaling, and cancer progression. Prog Mol Biol Transl Sci. 2013; 116: 409-32.

PubMed Abstract | Publisher Full Text

45. Anastasiadis $\mathrm{PZ}$, Reynolds $\mathrm{AB}$ : The $\mathbf{p} \mathbf{1 2 0}$ catenin family: complex roles in adhesion, signaling and cancer. J Cell Sci. 2000; 113(Pt 8): 1319-34. PubMed Abstract

46. Reynolds AB: p120-catenin: Past and present. Biochim Biophys Acta. 2007; 1773(1): 2-7.

PubMed Abstract | Publisher Full Text | Free Full Text

47. Carnahan RH, Rokas A, Gaucher EA, et al:: The molecular evolution of the p120-catenin subfamily and its functional associations. PLoS One. 2010; 5(12): e15747.

PubMed Abstract | Publisher Full Text | Free Full Text

48. F Anastasiadis PZ, Moon SY, Thoreson MA, et al:: Inhibition of RhoA by p120 catenin. Nat Cell Biol. 2000; 2(9): 637-44.

PubMed Abstract | Publisher Full Text | F1000 Recommendation

49. F Wildenberg GA, Dohn MR, Carnahan RH, et al:: p120-catenin and p190RhoGAP regulate cell-cell adhesion by coordinating antagonism between Rac and Rho. Cell. 2006; 127(5): 1027-39. PubMed Abstract | Publisher Full Text | F1000 Recommendation

50. Zebda N, Tian Y, Tian X, et al.: Interaction of p190RhoGAP with C-termina domain of p120-catenin modulates endothelial cytoskeleton and permeability. J Biol Chem. 2013; 288(25): 18290-9.

PubMed Abstract | Publisher Full Text | Free Full Text

51. F Noren NK, Liu BP, Burridge K, et al:: p120 catenin regulates the actin cytoskeleton via Rho family GTPases. J Cell Biol. 2000; 150(3): 567-80. PubMed Abstract | Publisher Full Text | Free Full Text | F1000 Recommendation

52. Delva E, Kowalczyk AP: Regulation of cadherin trafficking. Traffic. 2009; 10(3): 259-67.

PubMed Abstract | Publisher Full Text | Free Full Text

53. Wirtz-Peitz F, Zallen JA: Junctional trafficking and epithelial morphogenesis. Curr Opin Genet Dev. 2009; 19(4): 350-6. PubMed Abstract | Publisher Full Text | Free Full Text

54. de Beco S, Amblard F, Coscoy S: New insights into the regulation of E-cadherin distribution by endocytosis. Int Rev Cell Mol Biol. 2012; 295: 63-108.

PubMed Abstract | Publisher Full Text 
55. F Nanes BA, Chiasson-MacKenzie C, Lowery AM, et al.: p120-catenin binding masks an endocytic signal conserved in classical cadherins. J Cell Biol. 2012; 199(2): 365-80.

PubMed Abstract | Publisher Full Text | Free Full Text | F1000 Recommendation

56. F Magie CR, Pinto-Santini D, Parkhurst SM: Rho1 interacts with p120ctn and alpha-catenin, and regulates cadherin-based adherens junction components in Drosophila. Development. 2002; 129(16): 3771-82. PubMed Abstract | F1000 Recommendation

57. F Myster SH, Cavallo R, Anderson CT, et al.: Drosophila p120catenin plays a supporting role in cell adhesion but is not an essential adherens junction component. J Cell Biol. 2003; 160(3): 433-49.

PubMed Abstract | Publisher Full Text | Free Full Text | F1000 Recommendation

58. F Mayers JR, Wang L, Pramanik J, et al:: Regulation of ubiquitin-dependent cargo sorting by multiple endocytic adaptors at the plasma membrane. Proc Natl Acad Sci U S A. 2013; 110(29): 11857-62.

PubMed Abstract | Publisher Full Text | Free Full Text | F1000 Recommendation
59. F Gu M, Liu Q, Watanabe S, et al.: AP2 hemicomplexes contribute independently to synaptic vesicle endocytosis. eLife. 2013; 2: e00190. PubMed Abstract | Publisher Full Text | Free Full Text | F1000 Recommendation

60. F Shafaq-Zadah M, Brocard L, Solari F, et al:: AP-1 is required for the maintenance of apico-basal polarity in the $C$. elegans intestine. Development. 2012; 139(11): 2061-70.

PubMed Abstract | Publisher Full Text | F1000 Recommendation

61. F Gillard G, Shafaq-Zadah M, Nicolle O, et al:: Control of E-cadherin apical localisation and morphogenesis by a SOAP-1/AP-1/clathrin pathway in C. elegans epidermal cells. Development. 2015; 142(9): 1684-94. PubMed Abstract | Publisher Full Text | F1000 Recommendation

62. Loveless T, Hardin J: Cadherin complexity: recent insights into cadherin superfamily function in C. elegans. Curr Opin Cell Biol. 2012; 24(5): 695-701. PubMed Abstract | Publisher Full Text | Free Full Text

63. Pettitt J: The cadherin superfamily. WormBook. 2005; 1-9. PubMed Abstract | Publisher Full Text 


\section{Open Peer Review}

\section{Current Peer Review Status:}

\section{Editorial Note on the Review Process}

Faculty Reviews are review articles written by the prestigious Members of Faculty Opinions. The articles are commissioned and peer reviewed before publication to ensure that the final, published version is comprehensive and accessible. The reviewers who approved the final version are listed with their names and affiliations.

\section{The reviewers who approved this article are:}

\section{Version 1}

\section{Carien Niessen}

Center for Molecular Medicine, University of Cologne, Cologne, Germany

Competing Interests: No competing interests were disclosed.

2. David Sherwood

Department of Biology, Duke University, Durham, NC, USA

Competing Interests: No competing interests were disclosed.

\section{Albert Reynolds}

Department of Cancer Biology, Vanderbilt University Medical Center, Nashville, TN, USA

Competing Interests: No competing interests were disclosed.

The benefits of publishing with F1000Research:

- Your article is published within days, with no editorial bias

- You can publish traditional articles, null/negative results, case reports, data notes and more

- The peer review process is transparent and collaborative

- Your article is indexed in PubMed after passing peer review

- Dedicated customer support at every stage

For pre-submission enquiries, contact research@f1000.com 